\title{
Public Service Delivery and e-Governance: The Case of Pakistan
}

\author{
Asif Zaheer Shaikh ${ }^{1}$, Ume Laila Shah ${ }^{2}$, Chamila Wijekuruppu ${ }^{1}$ \\ ${ }^{1}$ Edith Cowan University, Western Australia \\ ${ }^{2}$ National University of Science and Technology, Pakistan
}

\begin{abstract}
Effective Public Service Delivery (PSD) remains a challenging task for Public Sector Management (PSM) in most developing countries. Pakistan has developed its Information and Communication Technology (ICT) and introduced e-governance. However, there remains an increasing gap between government and citizens in context of service delivery. There are number of possible barriers towards successful implementation of e-governance in the country. This paper aims to:

- Study key contrasts between manual and electronic PSD systems and its association with good governance, decentralisation, and socioeconomic development;

- Highlight the justification to e-governance and its benefits for the Government of Pakistan (GoP);

- Identify the key objectives for the GoP to successfully entrench e-governance with all stakeholders; and

- Identify policy options for the GoP with valued recommendations, which includes institutional and cultural reforms with electronic-Public Service Delivery (e-PSD).
\end{abstract}

\section{Introduction}

The Public Sector Management (PSM) have numerous challenges in providing effective public services, particularly in the least developed economies, as these services are provided through manual working systems, with lower level of transparency and accountability. Red-tape, political influence and inefficient bureaucratic approaches create more issues in this regard. Resultantly, the public feel deprived and stressed for not receiving essential services such as health, education, electricity, gas, sanitation, security and clean drinking water. This is an impediment not only for socioeconomic development but also for good governance and decentralisation of the system. One of the objectives of this paper is to study PSD and understand the key contrasts between manual and ePSD systems and its association with good governance, decentralisation, and socioeconomic development in case of Pakistan.

The terms E-government or e-governance can be defined as "the use of ICT in public sector with the aim of improving information and service delivery, encouraging citizen participation in the decision- making process and making government more accountable, transparent and effective" [1]. There is a wide debate among researchers, regarding above terms. E-government, is the use of emergent ICT to render the government services, to facilitate government operations and to engage citizens [2] whereas E- governance is the use of ICT to support the governing process and public administration [3].

There are three main target groups in egovernance: the government; business/interest groups; and the citizens. It is important to understand the three types of electronic interactions between these target groups, in e-government: government-to-government (G2G); government-to-business (G2B); and government-to-citizen (G2C). The external strategic objectives of e-governance focus on business/interest groups, while internal objectives focus on government itself [4].

Decentralisation genuinely shifts the authority and responsibility from the central government to local governments, which in turn provide quick decision making processes and fast delivery of services to the general public. It brings good governance and ensures the rights of every citizen. This type of governance is supported by a number of developed countries, scholars and renowned organizations such as International Monetary Fund (IMF), World Bank and United Nations (UN) [5].

However, a question arises that does it happen in a real sense? In number of developing countries, although there is a long regime of decentralized governments, there is still a concern that institutes and officials seem failed to perform their duties according to required standards of providing social assistance to citizens. This happens either due to political interference or their personal interests. Consequently, a local citizen does not receive benefits of righteous services, properly or timely [6]

The efficiency of public administration can be enhanced through innovation and e-government, whereby it can provide better services and respond to demands for transparency and accountability. Egovernment can help governments go-green and promote effective natural resource management, as well as stimulate economic growth and promote social inclusion, particularly to the disadvantaged and vulnerable groups. ICT systems are effective platforms for knowledge sharing, skills development, transfer of innovative e-government solutions and 
capacity-building. Furthermore, implementation of egovernment can generate important benefits in the form of new employment, better health and education, which improves the sustainable development of any country [7].

\section{Importance of Public Service Delivery (PSD)}

PSD plays a vital role in transparent transfer of cash and in-kinds and reduces economic inequality. It also accelerates social and human functioning of a country. In case of market failure, and when the disadvantaged cannot afford to purchase essential goods and services, it is the responsibility of the state to provide incentives or basic goods and services to protect them from further miseries.

PSD is required for the survival and the development of developing countries. Efficient PSD is a great concern for socio-economic development of a country. Further, various researches have claimed that there is a strong relationship between transparent public service delivery system and economic development [8]. Countries like Indonesia and Philippines are progressing more in PSD, this progress is mainly due to development of ICT in public institutes. While, South Asian (SA) countries such as Pakistan, Bangladesh and India are far behind in the advancement. Many developing countries lacks in computerised mechanism of national identity cards, voting cards, community score cards, social audit and community participation and grievance redress mechanisms that enhance fairness of the process. Due to absence of ICT, these mechanisms are manipulated, and provide undue advantage or control over the government system. ICT will prevent these malfunctions by symmetrical information and control at every step. Efficient public services and effective management of resources lead to improved quality of decentralization [9]. In this policy paper, the key question is, "In what way the electronic public delivery services (e-PSD) improve the socioeconomic development, decentralization and good governance"?

\section{ICT and e-government in Pakistan}

GoP has given a considerable attention to the implementation of ICT and e-governance in the country. However, despite all endeavours of government for establishing ICT system and thereby moving towards e-government with an enhanced PSD, the country still remain in the lower levels of world's e-government ranking. Notwithstanding the least improvement in ICT, citizen of Pakistan identifies PSD as one of their major concerns.

\subsection{The developing nation}

Pakistan is one of the developing countries of the world. It is located in the southern region of the Asian continent. The inception of e-government in Pakistan was held in October 2002, and still the ICT development is in its initial phase. Under the control of Ministry of Science and Technology, a unit called the Electronic Government Directorate (EGD) was founded. The aim of the unit was to manage egovernment projects and setting the standards for infrastructure and software in the information and technology (IT) field. There were a number of significant steps taken by the GoP for modernising the social and economic conditions of the country and improving ICT services. In this regard followings are some key achievements of GoP:

1. According to the annual report 2014 of Pakistan Telecommunication Authority (PTA) [10], the tele density has been reached at $79.8 \%$ in the Financial Year (FY) 2014 against 75.2\% in FY 2013, where the cellular sector is a major contributor.

2. Meanwhile, in the FY 2014, the number of broadband users reached at 3.79 million against 2.72 million in FY 2013 showing a growth of 39\% [10].

3. The PTA announced 3G / 4G Mobile Services in 2014 through auction and ended with a total of US\$1.11 billion at the end of FY 2014 [10].

4. Many infrastructure and application development projects were completed in the public sector. One of such applications is ,e-Office Suite ${ }^{\text {ee }}$ implemented in public institutes.

5. The National Database Registration Authority (NADRA) project was implemented to ensure the registration of personal data and the implementation of machine readable passports [11].

\subsection{E-government ranking}

E-governance is at its early stage in the developing world and facing challenges mainly at the implementation phase.

In this regard, despite overall development of ICT and Pro-ICT agendas of the GoP, Pakistan is still facing challenges for example, poor literacy rate for using ICT, sluggish development and adoption of e-government and poor infrastructure for IT.

Figure 1 shows how the literacy rate in Pakistan has changed over time from 1951 to 2009 [12].

A survey on e-government conducted by United Nations (UN) in 2014 revealed that the e-government ranking of Pakistan has declined from 156 in 2012 to 158 in 2014 as shown in Table 1. 


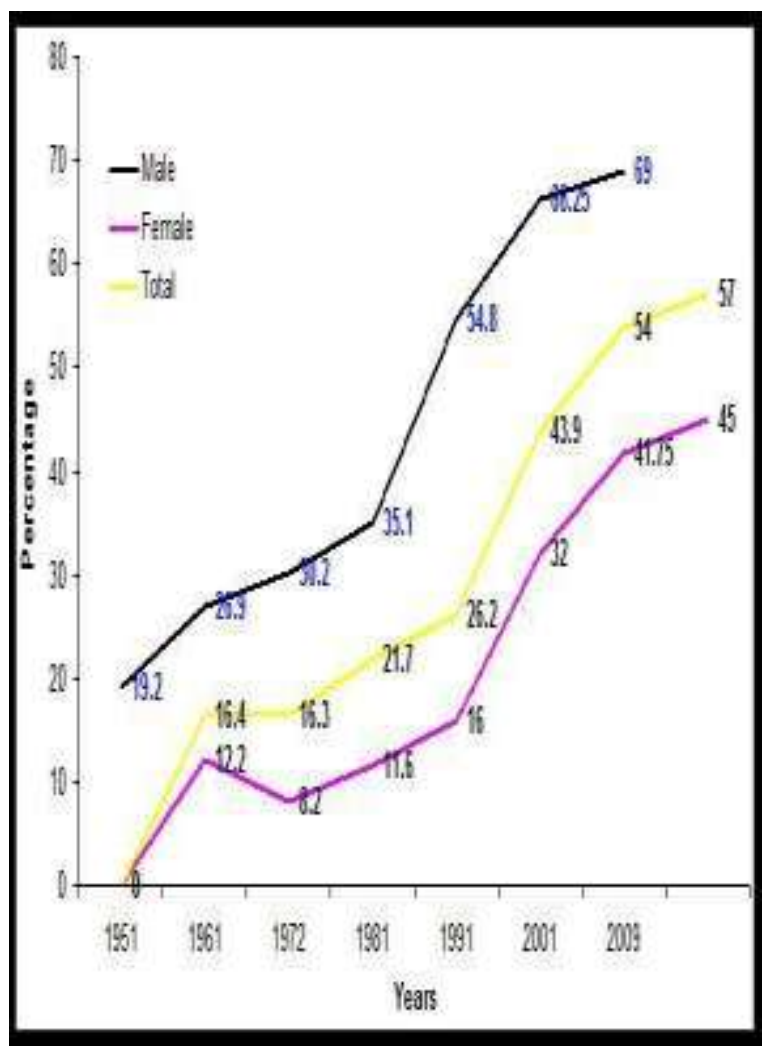

Figure.1. Literacy rate in Pakistan (1951-2009)

According to the same report, some countries in SA region such as Afghanistan and Bhutan are standing with significant improvements while Sri Lanka reported the highest improvement ahead of all other countries of the region.

Table1. United Nation's E-Government Development Index (EGDI)

\begin{tabular}{|l|c|c|l|l|l|}
\hline $\begin{array}{c}\text { Name of } \\
\text { country }\end{array}$ & $\begin{array}{r}\text { EGDI } \\
\mathbf{2 0 1 4}\end{array}$ & $\begin{array}{r}\text { EGDI } \\
\mathbf{2 0 1 2}\end{array}$ & $\begin{array}{l}\text { Rank } \\
\mathbf{2 0 1 4}\end{array}$ & $\begin{array}{l}\text { Rank } \\
\mathbf{2 0 1 2}\end{array}$ & $\begin{array}{c}\text { Change } \\
\text { in Rank }\end{array}$ \\
\hline Maldives & 0.4813 & 0.4994 & 94 & 95 & 1 \\
\hline Iran & 0.4508 & 0.4876 & 105 & 100 & -5 \\
\hline Sri Lanka & 0.5418 & 0.4357 & 74 & 115 & 41 \\
\hline India & 0.3834 & 0.3829 & 118 & 125 & 7 \\
\hline Pakistan & 0.2580 & 0.2823 & 158 & 156 & -2 \\
\hline Bangladesh & 0.2757 & 0.2991 & 148 & 150 & 2 \\
\hline Bhutan & 0.2829 & 0.2942 & 143 & 152 & 9 \\
\hline Nepal & 0.2344 & 0.2664 & 165 & 164 & -1 \\
\hline Afghanistan & 0.1900 & 0.1701 & 173 & 184 & 11 \\
\hline
\end{tabular}

A research conducted by Abbas and Ahmed in Pakistan, involved a survey with 800 households around the country [12]. The study comprised of interviews and focus group discussions. The findings of the research revealed that, the respondents were aware of the basic services but they do not receive those services. The study found that approximately $54.6 \%$ of total respondents identified that lack of social services delivery, is the major issue that affects the society of Pakistan. Furthermore, 53.3\% of the respondents identified the unemployment as the major issue while $36.8 \%$ responded that law and order situation of the country is main problem, while out of total 800 households, $28.9 \%$ indicated that corruption is the major issue that negatively affects the society of Pakistan.

\section{Approach to e-governance}

E-governance has been identified as an effective solution for most of the issues that the citizens have to undergo in relation to manual PSD systems with least transparency and accountability. However, incorporating e-governance into the existing system of a country should be done with a greater consideration of potential problem areas and also with a deeper understanding on the context. A proactive approach to address some of the potential barriers that might hinder the successful implementation of e-governance in Pakistan remains highly important in this regard.

\subsection{Key e-government barriers and considerations}

According to Mayer-Schonberger and Lazer,

“...three key issues, with respect to why agencies might under invest in technology, especially technologies that link them to other agencies and the public, are: 1) A collective action problem among organisations with respect to information sharing systems 2) Principal agent problems raised by sharing information among organisations and between government and society 3) Coalitional politics within organisations" [13].

These issues are the highlighted areas of potential concern that can undermine the intended vision to incorporate robust e-governance systems. Consideration to the collective approach of accessing information via ICT must be defined and implemented. Consideration to the standardisation and the actual acceptance of the technology used between organisations, government and citizens may create problems in the transformation of shared information. For example, if an organisation is using different technologies, the cost impacts to that specific organisation may be substantial.

These may include hardware, software and human capital cost impacts [14]. However, by placing ICT within the e-government sphere, it will allow a truer transparency of actions by the GoP. Governments may have particular interests in preventing some information flowing to the public as described by Mayer-Schonberger and Lazer [13].

Further consideration to ICT literacy may effect to the implementation strategy for e-government. The statistics provided by The World Bank suggests that the GoP may have concern with the indicated computer ownership currently recorded at $12 \%$ of the total population of Pakistan, while global median computer ownership is $32 \%$ as shown in Figure 2 [14]. 


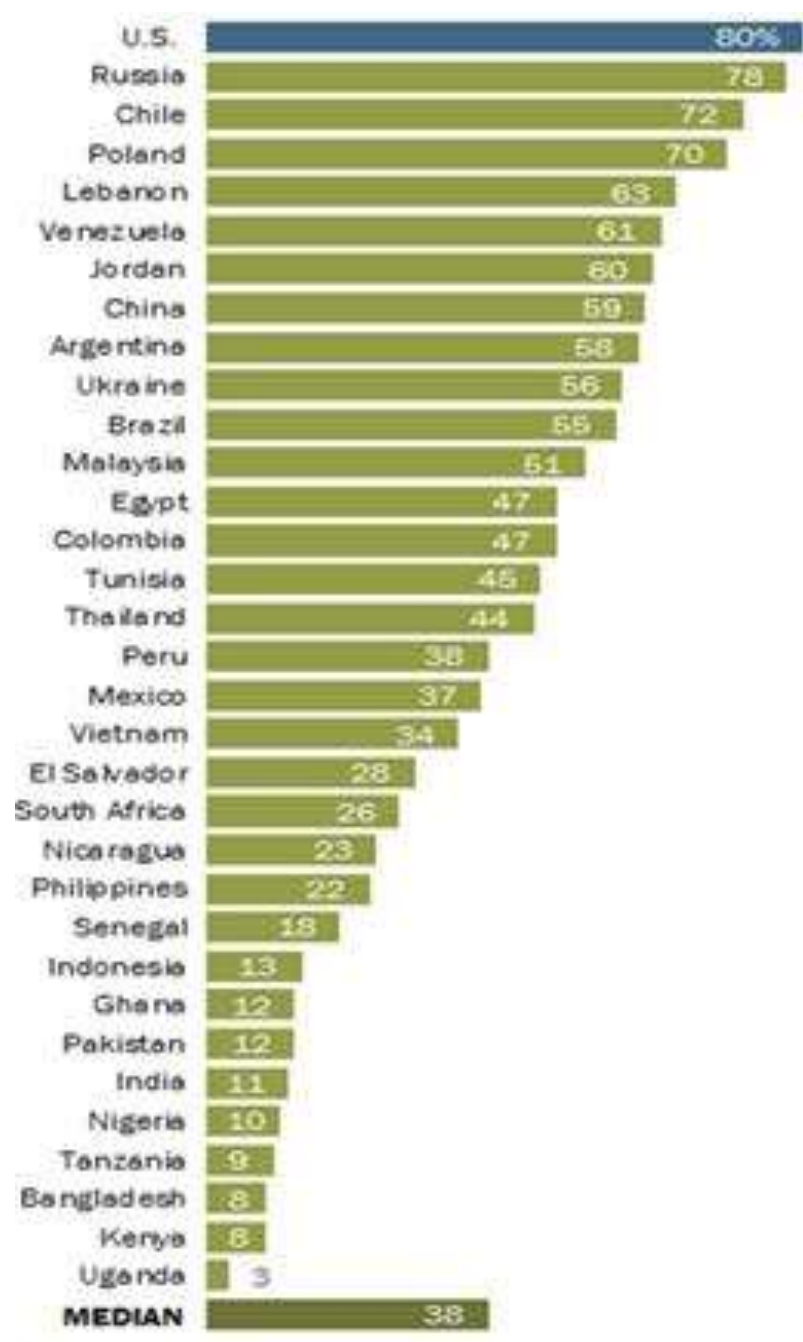

Figure 2. Global computer ownership

To embed ICT literacy within the population, strategies towards improving computer ownership and smart devices that can access the internet services to support the functionality of egovernment, will require further thought. While, in review of the collective approach of ICT software for easier interoperability, consideration to the overall population's access to computer, is also important.

The beginning of World Wide Web (www) support for development of one-window service centre model. Government official portals on internet can provide easy and prompt solution to number of public issues and serve them in a cost effective manner. Apart from accessing the required information, citizens can contact government representatives through email or online forums regarding any public issue. Resultantly IT is transforming the traditional way of public administration into a digital era. Table 2 illustrates the paradigm shift in PSD. In bureaucratic paradigm public managers focus on cost-efficiency while in egovernment paradigm managers stress user satisfaction, control and flexibility. E-government paradigm emphasises on innovation, learning and entrepreneurship. In new paradigm all the services can be customised according to need and preferences, whereas public managers work as a team in horizontal hierarchy under multidirectional network and communicate directly to the public [15].

Table 2. Paradigm shift in public service delivery

\begin{tabular}{|c|c|c|}
\hline & $\begin{array}{c}\text { Bureaucratic } \\
\text { Paradigm } \\
\end{array}$ & $\begin{array}{c}\text { e-Government } \\
\text { Paradigm } \\
\end{array}$ \\
\hline Orientation & $\begin{array}{l}\text { Production Cost- } \\
\text { efficiency }\end{array}$ & $\begin{array}{l}\text { User satisfaction } \\
\text { and Control } \\
\text { flexibility }\end{array}$ \\
\hline $\begin{array}{l}\text { Process } \\
\text { Organization }\end{array}$ & $\begin{array}{l}\text { Functional } \\
\text { Rationality, } \\
\text { departmentalization } \\
\text { vertical hierarchy of } \\
\text { control }\end{array}$ & $\begin{array}{l}\text { Horizontal } \\
\text { Hierarchy, network } \\
\text { organization, } \\
\text { information sharing }\end{array}$ \\
\hline $\begin{array}{l}\text { Management } \\
\text { Principle }\end{array}$ & $\begin{array}{l}\text { Management by rule } \\
\text { and mandate }\end{array}$ & $\begin{array}{l}\text { Flexible } \\
\text { management, } \\
\text { interdepartmental } \\
\text { team work with } \\
\text { central coordination }\end{array}$ \\
\hline $\begin{array}{l}\text { Leadership } \\
\text { Style }\end{array}$ & $\begin{array}{l}\text { Command and } \\
\text { control }\end{array}$ & $\begin{array}{l}\text { Facilitation and } \\
\text { coordination, } \\
\text { innovative, } \\
\text { entrepreneurship }\end{array}$ \\
\hline $\begin{array}{l}\text { Internal } \\
\text { Communication }\end{array}$ & $\begin{array}{l}\text { Top down, } \\
\text { Hierarchical }\end{array}$ & $\begin{array}{l}\text { Multidirectional } \\
\text { network with } \\
\text { central } \\
\text { coordination, direct } \\
\text { communication }\end{array}$ \\
\hline $\begin{array}{l}\text { External } \\
\text { Communication }\end{array}$ & $\begin{array}{l}\text { Centralized, formal, } \\
\text { limited channels }\end{array}$ & $\begin{array}{l}\text { Formal and } \\
\text { informal direct and } \\
\text { fast feedback, } \\
\text { multiple channels }\end{array}$ \\
\hline $\begin{array}{l}\text { Mode of } \\
\text { Service } \\
\text { Delivery }\end{array}$ & $\begin{array}{l}\text { Documentary mode } \\
\text { and interpersonal } \\
\text { interaction }\end{array}$ & $\begin{array}{l}\text { Electronic exchange } \\
\text { non face to face } \\
\text { interaction }\end{array}$ \\
\hline $\begin{array}{l}\text { Principles of } \\
\text { service } \\
\text { Delivery }\end{array}$ & $\begin{array}{l}\text { Standardization, } \\
\text { impartiality, Equality }\end{array}$ & $\begin{array}{l}\text { Under } \\
\text { customization, } \\
\text { personalization }\end{array}$ \\
\hline
\end{tabular}

In order to achieve socio-economic development, GoP is required to shift the existing bureaucratic paradigm to e-government paradigm. Inspite of that in Pakistan almost every ministry has a web page with relevant information, yet access to those sites is poor and having only one-way interaction. A study conducted by Qaisar and Ahmad claims that the development process in Pakistan is facing hindrance because of inadequate provision of funds from the top management for development and improper implementation of e-governance projects [16].

Further the unstable political situation also affects the development of Pakistan. More often, most of the active projects that were started by the previous governments are halted when a different political party comes into government, this lead to the wastage of time and resources causing huge financial losses to the country. Although GoP offers a range of services to public, but due to poor IT policies, and insufficient ICT services in the country, end user does not get benefit [17]. Since the government services lacks the transparency due to manual delivery system, therefore the citizens are either required to bribe 
administers to receive basic services or they are affected by the biases of officials who provide the services. On the contrary e-delivery can provide an accurate system with accountability as well as transparency, thus it has the ability to improve the effectiveness of decentralised government systems. The "Digital Divide" has created the gap between stakeholders, while bridging this gap will improve the PSD system, good governance and socioeconomic development as well as reduce the corruption in any country. South Korea (SK) is one of such examples, where most of the public services are computerised and provided electronically. This shift significantly decreases the distress as well as the scope of corruption and nepotism in SK. When the prospective process of aligning overall governance to an e-process is further reviewed, the impacts of current legislation towards the new process and how current legislation needs to be reviewed to ensure the overarching legal risks are identifiable. In order to establish the intended changes effectively, solutions for the identified loopholes should be cascaded through the government policy governance. For example, within the Australian Public Sector, as described by Edwards, Halligan, Horrigon and Nicoll, whatever governance framework applies, there are important aspects of departmental, ministerial and even parliamentary oversight [18]. Internally for a particular government organisation, an approach to governing the processes of e-governance within the organisation can include aspects as shown in Figure 3.

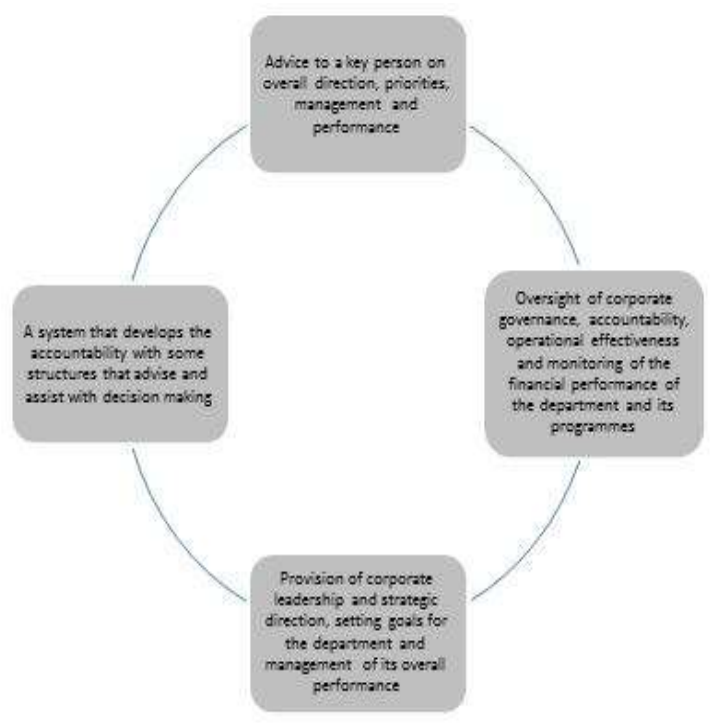

Figure 3. Aspects of an approach to e-governance

This can be aligned to the principles of egovernment strategies put in place in Singapore, whereby it was illustrated in a case study by MayerSchonberger and Lazer, (p.95) [13]:
"The self-conscious objective of e-government is to reduce transaction costs for government and the private sector; not included are initiatives to increase inclusiveness of process of governance ... The centrepiece of e-government is e-citizen: a one-stop shopping portal from which citizens can access all government services online..."

In appreciation of an already embedded egovernment process with sophisticated ICT, this is a proven benchmark of the progress that can be undertaken by the GoP to improve the quality of government services to public.

\section{E-governance objectives for GoP}

GoP is may develop the framework of egovernance with the help of four objectives such as enhanced social accountability, establishment of a digital service delivery system (DSDS), decentralisation of the system and socioeconomic development.

\subsection{Objective - I}

Social Accountability can be referred as the range of actions that public may exercise, apart from voting rights, to keep the government accountable, as well as the actions by the state, media, civil society and other key players in society that support these efforts. Social accountability can be deemed as new buzzword for development factors to identify the society and state ${ }^{e c}$ synergy which in turn can improve PSD. Major advantages of social accountability as, it can potentially lead to peoplecentric policies; public empowerment; improved PSD; and poverty alleviation. Accordingly, it can fortify the overall democratic process [19]. A compact framework for social accountability is provided by Affiliated Network for Social Accountability (ANSA) as shown in Figure 4.

This framework comprises of following four pillars:

1. Organised and capable public groups

2. Responsible government

3. Access to information

4. Culture and context sensitivity

These four pillars indicate the interaction between development, planning, budgeting, expenditure tracking and performance monitoring. Improved service delivery is attainable and it will support the welfare and rights of the citizens with increased participation between G2C and enhanced transparency in PSD process. 


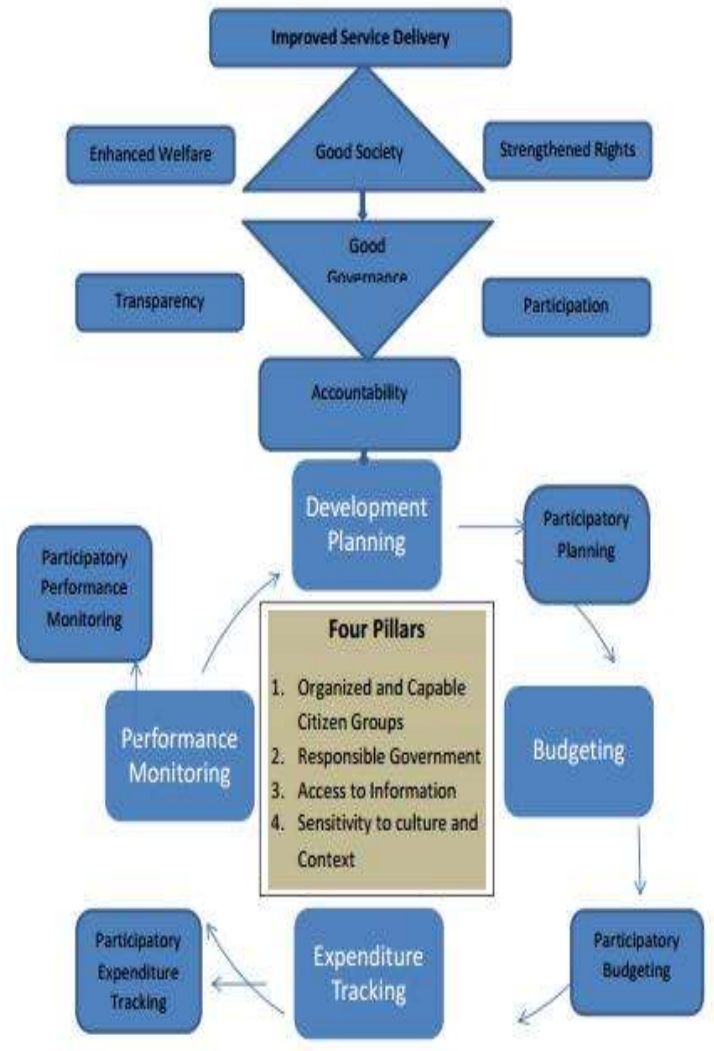

Figure 4. Framework for social accountability

However, efficient and effective mechanisms and functions essentially require citizens ${ }^{\text {ee }}$ participation.

According to Khadka and Bhattarai, various social accountability tools are being employed around the globe for example, participatory budgeting, checklist of entitlements, right to access, citizen charter, budget tracking, civic community score, citizen report card and civic education [20]. In a manual service delivery system, there is a little accountability and transparency and public is forced to wait or pay ,speed money ${ }^{\text {ee }}$ to obtain services in a number of public institutions such as police stations, land registration offices, government hospitals, municipal offices, and other social welfare offices. This occurs even in decentralised governance, because the manual record can easily be altered which causes delay or refusal in providing services or lead to favouritism to specific groups.

According to Khalid, Kamal, Noor, Akbar, Hasan, and Mahmud, the public in Pakistan is dissatisfied with government services mainly due to corruption whereas degree of corruption in Pakistan is rising due to lack of accountability [21]. People of Pakistan are suffering from poor system of health, education, roads, transportation, garbage disposal, sewerage system, water supply, law and order situation, electricity and gas supply.

DSDS fetches all basic services to the doorstep of citizens as per their convenience instead of visiting public offices and meeting public officers personally. Thus, it increases the transparency and accountability. Moreover, it decreases long queues, reduces turnaround time as well as guarantees a service without any hassle. Ultimately it improves the quality of decentralisation and socioeconomic development.

\subsection{Objective - II}

In Non-DSDS, service providers and service receivers get closer with each other and negotiate for undue services. For example, a person can negotiate with officials to get preference over others by paying illegal amount of money or through influence of high ups. In health organizations, normally government provide costly lifesaving drugs and vaccinations for poor and needy people as free of cost. However, in absence of DSDs, registers are maintained manually for in / out of stock and no information is provided publically, thus the inevitable outcome of the process is that the officials sell those medicines in blackmarket and earn illegal income. Also disadvantaged citizens meet medical officers personally and are placed into a position to bribe officials to obtain those medicines. Since there is no $\log$ or check balance system, the corruption can easily get expanded the country.

Under such system, receiving undue favouritism or priority by political influence or personal relations becomes easy for service seekers. At the same time, abusing power and providing services to ineligible persons for personal gains is also not difficult for the service providers. In contrast, in case of DSDS, all transactions are recorded with user IDs and other relevant data. It is therefore hard to manipulate records or misuse power and it also prevents corruption and nepotism as well as guarantees proper resource allocation. Not only this, but on the back end, the system maintains records for next future budget and strategic decisions which significantly supports for socioeconomic development.

\subsection{Objective - III}

In order to accelerate the country's economy, government needs to perform accordingly. While major determinant of good governance is providing public services effectively and efficiently with transparency. The core objective of decentralisation is to ensure that the state services are available at the doorstep of the general public promptly, transparently and properly. However, in Non-DSDS, although the service delivery can be assured through regulations but its effectiveness can be doubtful due to political interventions or dishonesty of immediate public officers. Furthermore, due to illegal intervention of local public representatives in public offices, the process of service delivery can be restricted by street level bureaucracy or it does not 
perform effectively. In this situation, the implementation of ICT in service delivery system as well as in personal office management can improve the quality of office management and provide better opportunities for good governance.

\subsection{Objective - IV}

Socioeconomic development is based on equity, social justice and appropriate resource allocation, whereas poor and cumbersome PSD systems curbs to flourish all these elements, it also creates asymmetry of information and hindrance for public participation in the development process. In order to ensure social economic development, the GoP needs to fight against real challenges for example, gap between citizens and local government, improper use of public resources, top down approaches for decision making and implementing process. ICT can bridge the gap between mismanagement and management, inefficiency and efficiency, and clear the path for social development.

\section{Policy options for GoP}

In view of above discussion, it is clear that good governance is essential for socioeconomic development, whereas good governance can be achieved through efficient and effective SDS, in this regard following policy options may be considered;

\subsection{PSD system}

ICT is considered as one of the major tools to manage public or private services, institutional or cultural reforms and community development approaches. It can indirectly monitor the government administration and empower citizens by providing easy access to valid information. According to Arfeen and Khan, using ICT for public sector may be based on three factors as shown in Figure 5 [22].

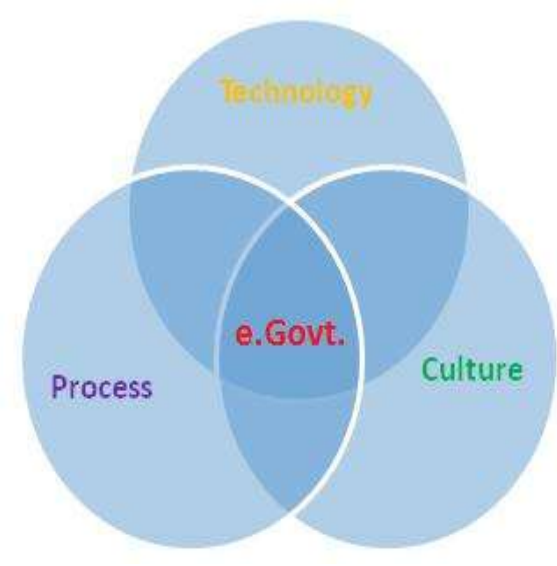

Figure 5. Factors for e-government
- Technology: Use of advanced information technology for implementation of changes

- Culture: Change in culture or behavior using manual procedure to ICT for those who are providing services and those who are receiving services

- Process: The advanced process of providing services that leads to improved outputs by the government.

In Pakistan, despite increasing demand of ePSDS, the creation of ICT infrastructure is far behind the commitment required. One of the options to provide e-PSD system is that the GoP may design a specific policy guideline for updating the Departmental Register, National Population Register, service contents in English language with translation in local languages as well as provide training to staff to defuse the digital divide and educate and spread awareness at rural levels. This will support sustainable development and national security

\subsection{Privatisation of PSD system}

Privatising public institutes is quite risky and as per the constitution of Pakistan it is the prime responsibility of the GoP to facilitate public service. Private organisations may be efficient and have the capacity to improve the service quality in short term, however, in the long term without permanent institutional mechanism and proper governance by the public sector, the private sector may lose its interest. This can happen due to various reasons such as non-monitory benefits and favouritism. Therefore, the entire nation may become vulnerable to the failure and face its negative effects. Moreover, as the state is required to pay to the private sector for services, the government expenditures will also be increased.

\subsection{Institutional reforms}

In order to develop the institutions for effective ePSD systems, a policy reformation with the introduction of latest IT infrastructure and concepts is required. However, only a physical development of institutions without necessary determinants such as, service contents, implementation of ICT, registration of national population, departmental register and development of human capital, might not produce desired results for improvement of the delivery system. After the establishment of proper infrastructure, GoP should introduce IT reforms with the objective to minimize the paperwork in national and local institutes and emphasize to fill and submit online applications. In this regard, a regulatory framework is necessary to prevent violation. However, while devising policies, the focus should be on establishing fair and equitable conditions based on the open access and free market. Although the cost of infrastructure is far more than the cost of 
privatization but in context of future demand, institutional reform is the best practice to develop PSD system. In order to finance the institutional change, public private partnership as well as donor organizations can be used as source.

\subsection{Cultural reforms}

Capacity building plays a vital role in cultural reforms. Generally, it is difficult to change the society's behaviour particularly in developing countries like Pakistan where poverty, illiteracy and week implementation of law remain as major obstacles. However, implication of ICT creates transparency and openness which can control bad cultural practices such as bribe or biases.

\subsection{Higher salary and more manpower}

It is widely understood that increase in salary will increase in motivation of employees [23]. This strategy in public institutes may motivate employees and results in better service delivery. Besides that, hiring optimum manpower will also provide positive result in the public sector. However, these steps will also increase the pressure on the national budget. Moreover, for achieving better performance, other strategies are also crucial. According to researchers, in order to improve the working environment, an organisation requires visionary and skilled leadership as well as monitoring and team building approaches. Furthermore, such organisations should have effective evaluation methods such as $360^{\circ}$ self/peer review methods and application of latest possible technologies [24].

\subsection{Community based approach}

According to some learned persons, the bottom up approach in the development process is better than the top down approach. It empowers the public by getting them involved in decision making process and whistle blow against culprits and backdrops. Mostly local people do not take their life's major decisions, instead community leaders control them. In Pakistan, community leaders more often are those who are strong and wealthy, supported by political parties. Therefore, the poor people in a community are afraid to critique the leaders directly for any injustice. Meanwhile, due to asymmetric information and illiteracy, people are not aware for their own rights as citizens of the country.

Citizens can be empowered by education, information and participation which would indirectly improve the quality of public services. ICT can play a vital role in bridging the gap between community and the government. The GoP may ensure the citizen's participation by providing them access to information of public resources, access to political leaders and also the opportunity to examine egovernance issues. This in turn will develop a sense of ownership within the general public.

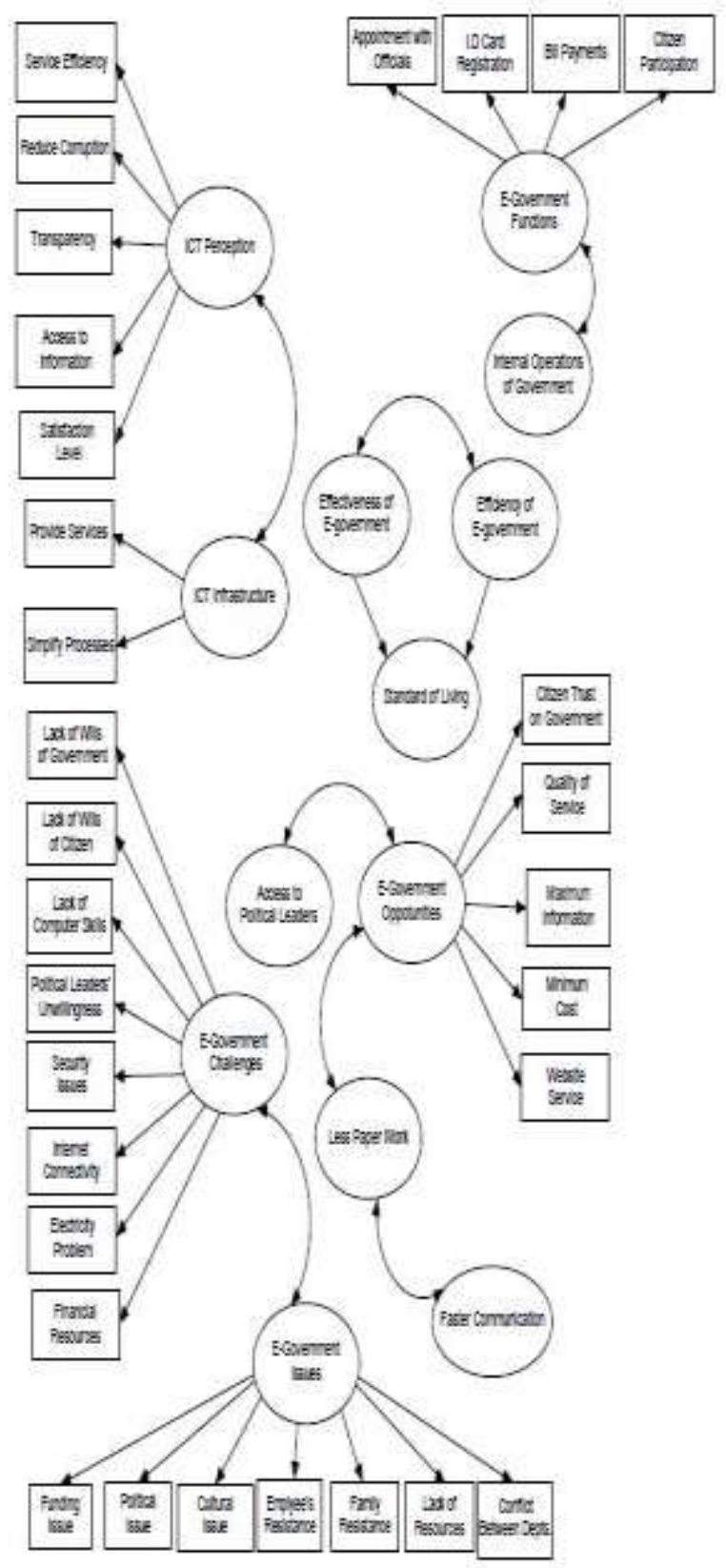

Figure 6. Factors involved in e-governance

Figure 6 provides a map of all impacts involved in the creation of policies and the implementation of e-governance.

Key variables include:

- ICT infrastructure;

- ICT perception;

- E-government opportunities;

- E-government issues;

- E-government functions;

- Communication improvement; and

- Effectiveness of e-government. 


\section{Recommendations}

The main objective of good governance and decentralisation is to decrease corruption and to ensure transparency. In view of above background, objectives, and policy options following recommendations can be considered for an effective PSD in Pakistan:

Implementation of ICT: It can bridge the gap between institutions and culture, consideration to a public/private partnership could be the better solution to finance the ICT infrastructure and its smooth operation.

ICT and broadband improvement: All public institutes should be facilitated with intranet and high speed internet bandwidth, advanced hardware and software as it plays major role in performance of egovernance.

Trust Building: It is a foremost component for sustainable relationship. Trust will strengthen the institutions as well as ordinary citizens and provide a ground for development of economy. In order to build trust among citizen and Government, it is essential to create a platform for maximum interaction between public and government institutes. ICT is considered as best way for interaction, it can play a vital role for receiving and disseminating the requests from public and response from government.

Government ICT applications: All ministries should improve their web portals with complete and updated institutional data as well as G2G and G2C interaction. All web pages should be in English with the option of local language translation.

E- forms: Citizens should be able to download all the relevant forms together with the details of the entire procedure as how to obtain that specific public facility. These forms should be submitted online to relevant line manager under the intimation to authorities with required turnaround time.

Cybercrime Law: Government with the support of cyber law bodies should implement cybercrime law to protect copy rights, business transactions and confidential data used in secured networks of the government for services such as e-Commerce and eBanking.

Financial impact consideration: GoP should take steps to provide internet facilities throughout the country on subsidised rates especially for rural areas.

\section{References}

[1] UNESCO. (2007). E-governance capacity building; http://portal.unesco.org/ci/en/ev.phpURL_ID=2179\&URL _ DO= DO_TOPIC\&URL_SECTION (23 August 2015).

[2] West, A. P., \& Wind, J. (1996). Beyond the Pyramids: Designing the 21st Century Enterprise. Wharton School, SEI Center for Advanced Studies in Management.
[3] Drucker, P. F. (2001). Electronic Governance on Context. Electronic Governance and Electronic Democracy: Living and Working in the Connected World: Commonwealth Centre for Electronic Governance.

[4] Backus, M. (2001). E-governance in Developing Countries. IICD Research Brief; www.iicd.org (23 October 2015).

[5] World bank Group. (2012).Administrative decentralization;http://www1.worldbank.org/publicsector/d ecentraliz ation/ admin.htm. (23 August 2015).

[6] Akram, S. M., Mahmud, T. \& Iftekharuzzaman.(2007). Integrity in Humanitarian Assistance: Issues and Benchmarks;www.ti-bangladesh.org/research(15 August 2015).

[7] United Nations. (2014). United Nations e-Government Survey 2014: E-Government for the Future We Want. New York: United Nations; https://publicadministration. un.org /egovkb/portals/egovkb/documents/un/2014-survey (24 August 2015).

[8] Shah, A. (2005). Public Services Delivery. Washington, DC: World Bank; https://openknowledge. worldbank. org/handle/10986/7424 License (23 September 2015).

[9] Azfar, O., Kahkonen, S., Lanyi, A., Meagher, P. \& Rutherford, D. (1999). Decentralization, Governance and the Public Service: The Impact of Institutional Arrangements. A Review of Literature. College Park: University of Maryland, IRIS Centre.

[10] Pakistan Telecommunication Authority. (2014). Annual Report;www.pta.gov.pk/index.php? option=com content \& view=article \&id=361\&Itemid=791Qai $\quad$ (5 August 2015).

[11] Government of Pakistan. Ministry of Information Technology (2005). E-Government Strategy and 5-Year Plan for the Federal Government; http://unpan1.un.org /intradoc /groups/public/documents (23 October 2015).

[12] Abbas, M. H., \& Ahmed, V. (2014). Challenges to social accountability and service delivery in Pakistan. The Sustainable Development Policy Institute; www.sdpi.org/ publications (Access date: 12 September 2015).

[13] Mayer-Schonberger, V., \& Lazer, D. (Eds.). (2007). From electronic government to information government. Cambridge, MA, USA: MIT Press.

[14] World Bank. (2011). The UN E-Government Survey: Towards a More Citizen-Centric Approach; http:// blogs. worldbank.org/publicsphere/un-e-government-surveytowards-more-citizen-centric-approach. (23 August 2015).

[15] Ho, T.K. (2002). Reinventing Local Governments and the E-Government Initiative. Public Administration Review, 62(4), pp. 434 - 444.

[16] Qaisar, N., \& Ahmad, H. G. (2010). E-Government Challenges in Public Sector: A case study of Pakistan. Global Journal of Management and Business Research, 10(8); http://www.journalofbusiness.org/index.php/ GJMBR/article/view/401 (23 September 2015). 
[17] Kayani, M. B., Ehsan ulHuq, M., Perwez, M. R. \& Humayun, H. (2011). Analyzing barriers in e-government implementation in Pakistan. International Journal for Infonomics (IJI), 4(3/4), pp. 494-500.

[18] Edwards, M., Halligan, J., Horrigan, B., \& Nicoll, G. (2012). Public sector governance in Australia. Canberra, Australia: The Australian National University, ANU E Press.

[19] Newell, P. \& Wheeler, J. (2006). Making Accountability Count: IDS Policy Briefing-The latest development issues for policy makers from the institute of development studies; www.ids.ac.uk/files/dmfile/PB33.pdf (5 August 2015).

[20] Khadka, K. \& Bhattarai, C. (2012). Source book of 21 social accountability tools; http://siteresources.world bank.org/PULICSECTOR-AND-GOVERNANCE /Resources (26 October 2015).

[21] Khalid, M. Y., Kamal, S., Dr. Noor, M. T., Akbar, S. H., Hasan, B., \& Mahmud, K. (2012). Social Audit of Local Governance and Delivery of Public Services in Pakistan 2011-2012: Pakistan National Report. Islamabad: UNDP; www.dtce.org.pk/dtce/public /sar.html (5 November 2015).

[22] Arfeen, M. I., \& Khan, N. (2009). Public Sector Innovation: Case Study of e-government Projects in Pakistan. The Pakistan Development Review. 48(4), pp 439-457.

[23] Stringer, C., Didham, T., \& Theivananthampillai, P. (2011). Motivation, pay satisfaction, and job satisfaction of front-line employees. Qualitative Research in Accounting \& Management, 8(2), pp. 161-179.

[24] Alexander, D. M. (2006). How do 360-degree performance reviews affect employee attitudes, effectiveness and performance?; www.uri.edu/research /lrc/ research/papers. Html (23 October 2015). 